Bio Core

Exploring Scientific Community
International Journal of Nutritional Science and Food Technology

\title{
Study on Effect of Carbonation on Storage and Stability of Pomegranate Fruit Juice
}

\author{
Dhinesh Kumar $\mathrm{V}^{* 1}$, D Ramasamy ${ }^{2}$, Jerish Joyner $\mathrm{J}^{3}$ \\ ${ }^{1}$ College of Food and Dairy Technology, Chennai, India. \\ ${ }^{2}$ Department of Food Science and Technology, CFDT, Chennai, India. \\ ${ }^{3}$ Department of Food Engineering, CFDT, Chennai, India.
}

Corresponding Author: Dhinesh Kumar. V, College of Food and Dairy Technology, Chennai, India. Email: dhineshfpe@gmail.

Citation: Dhinesh Kumar. V (2016), Study on Effect of Carbonation on Storage and Stability of Pomegranate Fruit Juice. Int J Nutr Sci \& Food Tech. 2:2, 17-21. DOI: 10.25141/2471-7371-2016-2.0048

Copyright: (C2016 Dhinesh Kumar.V et al. This is an open-access article distributed under the terms of the Creative Commons Attribution License, which permits unrestricted use, distribution, and reproduction in any medium, provided the original author and source are credited

Received: August 5, 2016; Accepted: September 20, 2016; Published: September 30, 2016

\section{Abstract}

Present investigation was undertaken to prepare carbonated beverage from pomegranate juice. Fruits of Ganesh variety were used in investigation. The yield of pomegranate juice obtained on whole fruit basis was 43 per cent while it was 68 per cent on aril weight basis. The carbonated beverage was prepared with $5,10,15,20$ percent pomegranate juice with blending of ginger juice at $1,2,3$ per cent by maintaining the TSS at 15 Brix and acidity 0.32 per cent. Based on the organoleptic evaluation, carbonated beverage with 10 per cent pomegranate juice and ginger juice 1 per cent was best among all the levels.

Key words: Pomegranate, Carbonated Beverage, Pomegranate Juice, Ginger Juice

\section{Introduction}

Pomegranate Fruit Pomegranate (Punica granatum L.) is one of the most important fruit crops in India because of its adaptable nature, high profitability and being cultivated on a commercial scale in temperate, tropical and subtropical regions of country [11]. Its fruits are good source of nutrients and bioactive compounds, mainly anthocyanins which exhibit strong chemo-preventive activities such as antimutagenicity, antihypertension, antioxidative potential and reduction of liver injury $[12,13]$. The edible part of the pomegranate is called aril which constitutes about $52 \%$ of total fruit $(\mathrm{w} / \mathrm{w})$, comprising $78 \%$ juice and $22 \%$ seeds $[10,4]$. Joseph Priestly (1767) invented carbonation process in which carbonated water was made by passing pressurized carbon dioxide through water. The pressure increases the solubility and allows more carbon dioxide to dissolve than would be possible under standard atmospheric pressure. When the bottle was opened, the pressure is released allowing the gas to come out of the solution, thus forming the characteristic bubbles.
A method of preparation of carbonated RTS beverages using pomegranate syrup was described .Preparation and storage of carbonated ready to serve (RTS) pomegranate beverage. The pomegranate syrup consisted of $100 \%$ fruit juice, $0.5 \%$ citric acid and brix was maintained at $65 \%$. The syrup was diluted to 5 times and then carbonated. Carbonated RTS beverage from acidic tamarind pulp was developed by exposing the pulp to mixture of food enzymes .Tamarind RTS beverage was prepared using 12.5\% tamarind extract, $0.4 \%$ acidity and adjusting to $16^{\circ}$ brix. It was demonstrated that carbonated coconut beverages packed in glass bottles with crown cork seal can be safely preserved for 6 months period at an ambient temperature range of $28-32^{\circ} \mathrm{C}$. Fruits like pomegranate, orange, amla and lemon because of high acidity and sharp taste are not palatable for direct consumption. To make them fit for human consumption and available throughout the year in the form of beverage, a reliable, controllable and reproducible technology has been developed for production of carbonated beverage with preservation of all the nutrients of the fruit. 
Compared to fruit juices the formulations of carbonated fruit beverage offers more variety of flavors nutrients long shelf life and other physiological benefits with a greater margin of safety in drink with a lower inherent cost. In the present study carbonated pomegranate beverage was successfully prepared from the pomegranate juice and physicochemical properties with sensory evaluation were studied.

\section{Materials and Methods}

\section{Pomegranate fruits}

Pomegranate fruits of ganesh variety were obtained from koyambedu anna fruit market from Chennai. The fruits of uniform size, color, and maturity were used for investigation.

\section{Moisture}

The moisture contents of the fruits were determined according to standard method. (Method 934.06 of AOAC, 1990).

Titratable

acidity Acidity of juice was determined by titration with $0.01 \mathrm{~N}$ sodium hydroxide [16]. The per cent acidity was expressed in terms of anhydrous citric acid.

Ash

The sample (5 g) was kept in a muffle furnace and ashed at a temperature not exceeding $525{ }^{\circ} \mathrm{C}$ for 6 hours. The ash was then cooled in a desiccator and weighed. The ash content was recorded as $\mathrm{g}$ per $100 \mathrm{~g}$-fresh weights $(\mathrm{g} / 100 \mathrm{~g}$-fw) (method 940.26 of AOAC, 1990).

\section{Sugars and soluble solids}

Total sugars, reducing sugars and total soluble solids content in the pomegranate fruits were estimated by following the procedures of 932.12 of AOAC (1990).

Total Soluble Solids (T.S.S) Total Soluble Solids were determined by using Abbes refractometer $\left(0-32^{\circ} \mathrm{Bx}\right)$ and expressed in degree brix $\left({ }^{\circ} \mathrm{Bx}\right)$.

Ascorbic acid

Determination of ascorbic acid was done by 2,6-dichlorophenolindophenol dye method suggested by Ranganna [16].

\section{Sugars}

Reducing, non-reducing and total sugars were determined by the methods of Lane and Eynon [12] with slight modifications suggested by Ranganna [16].

Anthocyanin content The total anthocyanin pigment were measured by the method of Flueki and Francis [16] with slight modification suggested by Khurdiya and Roy [9].

Organoleptic

Evaluation It has been long recognized that enjoyment of Food product is essential for good health. Enjoyment would mean choice, acceptance, nutrition and whole sameness. The 9 point hedonic scale for sensory evaluation has been used extensively since, its developments with a wide variety of products and with considerable success.

\section{Development and Characterization of a Carbonated} Pomegranate Beverage

The pure pomegranate extract was blended with food additives mentioned above in accordance with standard set by the World Health Organisation (WHO). The resulting solution is a pomegranate soft drink. Carbonation was done in carbonation pilot plant. To carbonate the product, it was first absorption of $\mathrm{CO} 2$, which was then added to the pomegranate soft drink with the aid of carbonator. The temperature and pressure of the carbonator gauge varied at 100 to $120 \mathrm{psi}$ and three different stages to vary the volume of $\mathrm{CO} 2$ in the pomegranate soft drink represented as sample A (Used $10 \%$ pomegranate juice), B (Used $12 \%$ pomegranate juice), $\mathrm{C}$ (Used $15 \%$ pomegranate juice) was carbonated. The product was then bottled and sealed immediately for freshness. The product (carbonated pomegranate drink) was then analysed to determine the chemical content, $\mathrm{pH}$, titratable acidity, brix, carbohydrate, protein and etc. Storage of the carbonated beverage

\section{Storage of carbonated beverage}

was done at two different condition viz., ambient storage ( 12.2$33.1 \mathrm{oC}$ ) and cool storage (5-8 oC) for a period of three months.

\section{Statistical analysis}

Statistical analysis of the results during storage of carbonated beverage of pomegranate juice was done according to the Factorial Completely Randomised Design (FCRD).

\section{Results and Discussion}

Physico-chemical characteristics of pomegranate fruit and juice

Fruits of pomegranate cv. Ganesh used in present investigation were having following physical as well as chemical properties.

\begin{tabular}{|l|c|c|c|}
\hline Characteristics & & Range & Average \\
\hline Color & & - & Pale yellow \\
\hline Length & {$[\mathrm{cm}]$} & $6.8-8.6$ & 7.4 \\
\hline Width & {$[\mathrm{cm}]$} & $8.9-9.3$ & 8.3 \\
\hline Weight & {$[\mathrm{gm}]$} & $250-340$ & 290 \\
\hline T.S.S. & {$\left[{ }^{\circ} \mathrm{Brix}\right]$} & $13.2-15.6$ & 13.60 \\
\hline Acidity & {$[\%]$} & $0.36-0.42$ & 0.48 \\
\hline pH & & $2.6-3.18$ & 3.30 \\
\hline Reducing sugars & {$[\%]$} & $10.20-12.50$ & 14.00 \\
\hline $\begin{array}{l}\text { Non-reducing } \\
\text { sugars }\end{array}$ & {$[\%]$} & $2.62-3.21$ & 3.88 \\
\hline Total sugars & {$[\%]$} & $12.46-16.40$ & 14.82 \\
\hline Ascorbic acid & {$[\mathrm{mg} / 100 \mathrm{ml}]$} & $12.10-16.80$ & 15.04 \\
\hline $\begin{array}{l}\text { Ant h o c y a in } \\
\text { content }\end{array}$ & {$[\mathrm{mg} / 100 \mathrm{ml}]$} & $16.20-22.30$ & 18.28 \\
\hline
\end{tabular}

Table.1 Physico-chemical characteristics of pomegranate fruit and juice 
The values of physico-chemical characteristics of pomegranate fruits and juice used in present investigation are comparable with those reported by Swaminathan (1977), Soodet al. (1982), Jagtap et al. (1992), Waskar and Deshmukh (1995) and Vaidya et al. (1998).

\begin{tabular}{|r|c|c|} 
Chemical composition of carbonated beverage prepared \\
\hline T.S.S. & {$\left[{ }^{\circ}\right.$ Brix $]$} & 15.00 \\
\hline Acidity & {$[\%]$} & 0.30 \\
\hline $\mathrm{pH}$ & & 2.90 \\
\hline Reducing sugars & {$[\%]$} & 13.70 \\
\hline $\begin{array}{r}\text { Non-reducing } \\
\text { sugars }\end{array}$ & {$[\%]$} & 0.92 \\
\hline $\begin{array}{r}\text { Total sugars } \\
{[\%]}\end{array}$ & 14.62 \\
\hline $\begin{array}{r}\text { Ascorbic acid } \\
\text { Anthocyanin } \\
\text { content }\end{array}$ & {$[\mathrm{mg} / 100 \mathrm{ml}]$} & 1.12 \\
\hline$[\mathrm{mg} / 100 \mathrm{ml}]$ & 1.81 \\
\hline
\end{tabular}

Table.2 Chemical composition of carbonated beverage prepared

Carbonated beverages of various compositions have been reported by several workers. The values of various chemical parameters of carbonated beverage prepared from $10 \%$ pomegranate juice and 1\% ginger juice are comparable with those reported by Khurdiya et al. (1989), Rokadeet al. (2001), Shelar (2001)and Jadhavet al. (2002).

Effect of ambient storage condition on chemical composition of carbonated beverage

\begin{tabular}{|c|c|c|c|c|c|}
\hline \multicolumn{6}{|c|}{ Storage duration (month) } \\
\hline Sr.No. & $\begin{array}{c}\text { Chemical } \\
\text { parameters }\end{array}$ & Initial & After 1month & After 2month & After 3month \\
\hline 1 & T.S.S. ( OBrix) & 15.00 & 14.40 & 16.20 & $*$ \\
\hline 2 & Acidity (\%) & 0.30 & 0.26 & 0.25 & $*$ \\
\hline 3 & $\mathrm{pH}$ & 2.90 & 3.30 & 3.30 & $*$ \\
\hline 4 & $\begin{array}{c}\text { Reducing sugars } \\
(\%)\end{array}$ & 13.70 & 14.70 & 14.15 & $*$ \\
\hline 5 & $\begin{array}{l}\text { Non-reducing } \\
\text { sugars }(\%)\end{array}$ & 0.92 & 2.21 & 2.05 & $*$ \\
\hline 6 & Total sugars $(\%)$ & 14.62 & 13.31 & 16.19 & * \\
\hline 7 & $\begin{array}{c}\text { Ascorbic acid } \\
(\mathrm{mg} / 100 \mathrm{ml}) \\
1.14\end{array}$ & 1.14 & 1.08 & 1.00 & $*$ \\
\hline 8 & $\begin{array}{c}\text { Anthocyanin } \\
\text { content (mg/100 } \\
\mathrm{ml})\end{array}$ & 1.84 & 1.45 & 0.96 & $*$ \\
\hline$*$ spoiled & & & & & \\
\hline
\end{tabular}

Table.3 Effect of ambient storage condition on chemical composition of carbonated beverage 
Effect of cool storage condition on chemical composition of carbonated beverage

\begin{tabular}{|c|c|c|c|c|c|}
\hline \multicolumn{6}{|c|}{ Storage duration ( month) } \\
\hline Sr.No. & $\begin{array}{c}\text { Chemical param- } \\
\text { eters }\end{array}$ & Initial & After 1month & After 2month & After 3month \\
\hline 1 & T.S.S. ( OBrix) & 15.00 & 15.30 & 15.60 & 16.10 \\
\hline 2 & Acidity ( \%) & 0.30 & 0.28 & 0.28 & 0.23 \\
\hline 3 & $\mathrm{pH}$ & 2.90 & 2.80 & 3.12 & 3.28 \\
\hline 4 & $\begin{array}{c}\text { Reducing sugars } \\
(\%)\end{array}$ & 13.74 & 13.72 & 13.88 & 14.16 \\
\hline 5 & $\begin{array}{l}\text { Non-reducing } \\
\text { sugars }(\%)\end{array}$ & 0.94 & 1.17 & 1.46 & 1.85 \\
\hline 6 & Total sugars $(\%)$ & 14.52 & 14.87 & 15.45 & 16.06 \\
\hline 7 & $\begin{array}{c}\text { Ascorbic acid (mg/ } \\
100 \mathrm{ml})\end{array}$ & 1.14 & 1.11 & 1.04 & 0.92 \\
\hline 8 & $\begin{array}{l}\text { Anthocyanin con- } \\
\text { tent }(\mathrm{mg} / 100 \mathrm{ml})\end{array}$ & 1.80 & 1.48 & 1.28 & 0.96 \\
\hline
\end{tabular}

Table.4 Effect of cool storage condition on chemical composition of carbonated beverage

The carbonated beverage prepared from pomegranate juice could be stored for two months in ambient condition storage and three months in cool storage condition. During storage of the carbonated beverage slight changes in chemical composition were recorded. Increase in T.S.S., pH, reducing sugars, non-reducing sugars and total sugars as well as decrease in titrable acidity, ascorbic acid and anthocyanin content was recorded in all treatments irrespective of storage condition . The rate of increase in T.S.S., $\mathrm{pH}$, reducing sugars, non-reducing sugars and total sugars as well as decrease in titrable acidity, ascorbic acid and anthocyanin content was higher in ambient condition than cool storage condition. Similar findings were reported by Khurdiya et al. (1996) and Shelar (2001).

Effect of ambient storage condition on organoleptic composition of carbonated beverage

\begin{tabular}{|c|c|c|c|c|c|}
\hline \multicolumn{7}{|c|}{ Storage duration ( month) } \\
\hline Sr.No & Organoleptic test & Initial & After 1month & After 2month & After 3month \\
\hline 1 & Taste & 8.5 & 8.4 & 7.0 & 6.0 \\
\hline 2 & Colour & 7.7 & 7.5 & 7.7 & $*$ \\
\hline 3 & Flavour & 8.2 & 7.8 & 8.2 & $*$ \\
\hline 4 & Overall & 8.5 & 8.4 & & $*$ \\
\hline
\end{tabular}

Table.5 Effect of ambient storage condition on organoleptic composition of carbonated beverage 
Effect of cool storage condition on organoleptic composition of carbonated beverage

\begin{tabular}{|c|c|c|c|c|c|}
\hline \multicolumn{9}{|c|}{ Storage duration ( month) } \\
\hline Sr.No & Organoleptic test & Initial & After 1month & After 2month & After 3month \\
\hline 1 & Taste & 8.5 & 8.3 & 8.3 & 7.8 \\
\hline 2 & Colour & 7.7 & 7.7 & 7.4 & 7.2 \\
\hline 3 & Flavour & 8.2 & 8.2 & 7.8 & 7.5 \\
\hline 4 & $\begin{array}{c}\text { Overall } \\
\text { acceptability }\end{array}$ & 8.5 & 8.6 & 8.4 & 8.2 \\
\hline
\end{tabular}

Table.6 Effect of cool storage condition on organoleptic composition of carbonated beverage

The score for all sensory attributes decreased gradually during storage period. The decrease in score for taste, flavor, colour and overall acceptability was rapid in ambient storage condition than cool storage condition Similar findings were reported by Khurdiya et al. (1996), and Shelar (2001).

\section{References}

1. Adsule, R.N. and Patil, N.B. (1995). Pomegranate inHandbookof Fruit Science and Technology.(D.K. Salunke and S.S. Kadam,Ed.) Marcel Dekker, Inc. New York.pp455-464.

2. Amerine, M.A., Pangborn, R.M. and Rosseler, E.B. (1965). Principles of SensorEvaluation of Food. Academic Press,London.

3. Jagtap, D.B., Desai, U.T. and Kale, P.N. (1992). Chemicalcomposition of indigenous and exotic cultivars of pomegranate.Maharashtra J. Hort., 6(1) : 10-12.

4. Khurdiya, D.S. (1989).Carbonation in fruit beverages.Beverage and Food World, 16(2) : 9-11.

5. Khurdiya, D.S.(1990). A study of fruit juice based carbonateddrinks. Indian Food Packer, 44(6) : 45-50.

6. Khurdiya,D.S.andRoy,S.K. (1984). Anthocyanins of qualityindex in jamunbeverages(Syzygiumcumini L).Indian FoodPacker,38(6) : 71-76.
7. Khurdiya, D.S. (1990). Orange concentrate based carbonatedbeverage. J. Food Sci. Technol.,27(5) : 394-396.

8. Khurdiya, D.S., Islam and Verma, O.P. (1996).Processing andstorage of carbonated guava beverage.J. Food Proc. andPreservation,20(1) : 79-86.

9. Lane, J.H. and Eynon, L. (1923).Determination of sugars byFehling solution with methylene blue as indicator.J. Soc. Chem. India, 42: 32-34.

10. More, T.A., Karale, A.R., Wasker, D.P. and Choudhari, S.M. (1999).Preparation of RTS and wine from pomegranate juice. Paper presented in training on post- harvest handling, processing and export of hort. crops held at Mahatma PhuleKrishiVidyapeeth, Rahuri., during July 14- August 3.

11. Ranganna, S. (1986).Handbook of Analysis and Qualitycontrol for Fruit and Vegetable Products.2ndEd. Tata McGrawHill Publication, New Delhi.pp.12-15. 